\title{
Dansa Yönelik Tutum Ölçeği Geliştirme Çalışması
}

\author{
DOI: $10.26466 /$ opus.552080 \\ * \\ Tebessüm Ayyıldız Durhan*
}

*Dr. Gazi Üniversitesi, Spor Bilimleri Fakültesi, Yenimahalle/ Ankara / Türkiye E-Posta: tebessum@gazi.edu.tr

ORCID: $\underline{0000-0003-2747-6933}$

Öz

Bu çalışmanın amacı bireylerin dansa yönelik tutumlarını ölçmeye dönük ölçme aracı geliştirmektir. Nitel veriler ve literatür ışığında oluşturulan 78 maddeden oluşan soru havuzu, maddeler uzman görüşleri alınarak 48 maddeye düşürülmüş, pilot çalışma sonrası oluşan ölçeğin denemelik formu Gazi Üniversitesi'nde ö̆grenim gören 306 ö̆grenci üzerinde uygulanmıştır. Elde edilen veriler üzerinde yapılan KMO (0.93) ve Barlett (6757.503; $p<0.001)$ testi sonucu örneklem sayısinın faktör analizi yapılması adına uygun olduğu belirlenerek, ölçeğin geçerliğine ilişkin bilgi elde edebilmek için döndürülmüş temel bileşenler analizi kullanılmışıtır. Kesme değerinin 0.40 olarak alındı̆̆ı açımlayıcı faktör analizi sonrası 0.53 ila 0.84 arasında değişen faktör yükleri ile ölçeğin üç alt faktörlü bir yapıya sahip olduğu

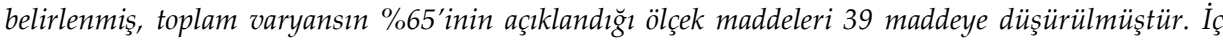
tutarlilı katsayları sirasiyla 0.96, 0.93, 0.90 olarak saptanan alt boyutlar dansa yönelik farkındalık, kaçınma ve motivasyon alt boyutları olarak adlandırılmıştır. Yapılan test tekrar test ile 296 katılımcıya ulaşılarak yapı geçerliliğine kanıt aranmıştır. Doğrulayıcı faktör analizi sonuçlarının (RMSA 0.072, SRMR 0.067, $x^{2} / d f 2.518$ ) yapıya kanıt oluşturacak nitelikte olduğu saptanmıştır. Sonuç olarak çalışmada analiz edilen ölçüm aracının dansa yönelik tutumu ölçmede geçerli ve güvenilir bir ölçüm aracı olduğu belirlenmiştir.

Anahtar Kelimeler: Dans, Tutum, Ölçek 


\title{
Development of Attitude ScaleTowards Dance
}

\begin{abstract}
The aim of this study is to develop a measurement tool to measure individuals' attitudes towards dancing. Qualitative data and the pool of questions consisting of 78 items formed in the light of the literature. the items were reduced to 48 items by taking expert opinions and the scale of the scale which was formed after the pilot study was applied on 306 students who were educated at Gazi University. Based on the data obtained from the KMO (0.93) and Barlett (6757.503; $p<0.001)$ test, it was determined that the number of samples was suitable for the factor analysis and rotated basic components analysis was used to obtain information about the validity of the scale. After the exploratory factor analysis, where the cutoff value was taken as 0.40. it was determined that the factor had a three-factor structure with factor loads ranging from 0.53 to 0.84 . The internal consistency coefficients were determined as $0.96,0.93$. 0.90 , respectively. The sub-dimensions were defined as awareness. avoidance and motivation sub-dimensions. With the test re-testing, 296 participants were searched for evidence of construct validity. Confirmatory factor analysis results (RMSA 0.072. SRMR 0.067. $x^{2} / d f 2.518$ ) were found to be evidence for the structure. As a result, it was determined that the measurement tool analyzed in the study was a valid and reliable measurement tool for measuring attitude towards dance.
\end{abstract}

Keywords: Dance, Attitude, Scale 


\section{Giriş}

Dans "İnsanın ruhsal durumunu bir takım bedensel hareketlerle ifade etmesini açığa vurması" olarak tanımlanmıştır (Emiroğlu ve Aydın, 2003). Zihnin doğadaki ritimleri algılaması veya müziğin tınısını duyarak, bilincin uyarılması sonucu bedenin, zamansal ve mekansal formlara göre hareket etmesidir (Tercan, 2016). Dans, her kültürde farklı bir anlama gönderme yapan ve çeşitliliğiyle zaman içinde taşıdığı veya kendisine atfedilen simgesel anlamların kaymasına uğrayabilen ya da anlam değişikliği yaşayabilen bedensel bir dışavurumdur. Dans ediminin ya da olgusunun, bireylerin yaşantılarındaki etkisinin saptanması, yapılan araştırmaların perspektifini değiştirmekle birlikte, ilintilenen kavramlarda da farklılıkların oluşmasına sebep olmuştur (Galioğlu, 2007). Dansın, bireyleri sosyalleştirirken, hayatımızı sürdürebilmemiz için şart olan toplumla uyumlu yaşamayı sağlayarak, aidiyet duygusunu tatmin ettiğini, bu sebeple de insan psikolojisine iyi gelerek; bireyin, diğer toplumsal alanlara katılımına yardımcı olması söz konusudur (Tercan, 2016). Aktaş'a (1999) göre; farklı boyutlara sahip olan dans insanın kendi duygu ve düşüncelerini anlatabilmesi ve toplumla bir iletişim kurabilmesi için anlam içeren hareketler topluluğunun, meydana getirdiği estetik ve ritmik özelliğe sahip bir yaratıcılığın sonucu olan fiziksel ve duygusal davranıştır. Bireylerin davranış biçiminin temelini oluşturan, belirleyici olan tutum faktörü ise; bir kimsenin ele alınan bir nesneye, bir duruma veya olaya karşı olan olumlu veya olumsuz tavrı olarak kabul edilir (Karakaş Türker ve Turanl, 2008). Tutulan yol, davranış olarak nitelendirilen (TDK, 2005) tutumların değişebilir ya da değiştirilebilir olduğu görülmektedir. Buna göre, olumsuz tutum olumlu, olumlu tutum ise olumsuz tutuma dönüşebilmektedir. Tutumların, düşünce ve davranışlara temel oluşturduğu, yönlendirdiği dikkate alındığında, bireyin başarıya yönlenmesinde olumlu tutum geliştirmenin gerekliliği göze çarpmaktadır. Tutum tanımlarına göre, bireyin duygu ve düşünceleri, davranışlarını etkilemektedir. Yani bu duygu ve düşünceler değiştiğinde, davranışlar da değişecektir. Tanımlardan da anlaşıldığ1 gibi, tutumu oluşturan üç öğe vardir:

- Bilişsel öğe

- Duyuşsal öğe 
- Devinişsel öğe (psikomotor öğe).

Bireyin tutum nesnesine ilişkin inançları, bilgi yapıları ve düşünceleri bilişsel öğe olarak adlandırılmaktadır. Bir tutum nesnesiyle ilgili edinilen bilgi, duyguları ve ardından davranışları etkilemektedir. Bu nedenle tutumun oluşumunda ilk basamak sayılabilir. Duyuşsal öğe; hoşlanma, sevme gibi duygusal tepkileri ifade etmektedir. Duyuşsal öğesi ağır basan bir tutumun değişmesi daha zor olmaktadır. Devinişsel öğe, bireyin düşünce ve duyguları doğrultusunda bir tutum nesnesine ilişkin davranış eğilimini ifade etmektedir. Bazı durumlarda düşünce ve duygulara göre davranış gösterilmese de, her bireyde bu düşünce ve duygulara göre davranış gösterme eğilimi bulunmaktadır. Tutumun bilişsel, duyuşsal ve devinişsel öğeleri arasında iç tutarlılık olduğu varsayılmaktadır. Bu üç tutum öğesi karşlıklı etkileşim içindedir. Birinde değişiklik olduğunda, diğer öğelerde de değişiklik görülmektedir. Örneğin amcasına karşı olumlu tutum geliştirmiş bir çocuk, amcasının önceden bir hırsızlık yaptığını öğrendiğinde (bilişsel öğe), onu eskisi gibi sevmez (duyuşsal öğe) ve bir daha onunla parka gitmez (devinişsel öğe) (Uçal Canakay, 2006). Bireylerin tutumlarını öğrenebilmek için duygu, düşünce ve davranışlarına bakılması gerektiği görülmektedir. Bireylerin davranışlarını gözlemlemek mümkündür. Ancak bu her zaman bireyin tutumunu tam olarak açıklamayabilir. Ayrıca var olan bir tutum düşünce boyutunda kalmış ama davranışa dönüşmemiş de olabilir. Bu nedenledir ki bireylerin tutumlarını ölçmek için değişik tutum ölçerler geliştirilmiştir (Koçakoğlu ve Türkmen, 2010). Bir nesneye, objeye ya da bireye yönelik tutumun belirlenmesi birkaç yolla sağlanabilir. Bunlar, fizyolojik tepkilerden vardama, açık davranışlardan vardama ve ölçek geliştirmedir (Kan ve Akbaş, 2005). Bu çalışma kapsamında ölçek geliştirme çalışması uygulanmıştır. Bireylerin dansa yönelik tutum düzeylerini ölçmek amacıyla kullanılabilecek bir ölçek geliştirmek amaçlanmıştır.

\section{Yöntem}

\section{Çalışma grubu}

Çalışmada soru havuzunun denemelik forma dönüşmesinden sonra sonra ölçüm aracının anlaşılabilirliğini test etmek amacıyla form 50 
öğrenciye uygulanarak sınanmıştır. Formun genel hatlarıyla anlaşılabilir olmasının belirlenmesi ile ilk uygulamaya geçilmiş, ilk uygulama Gazi Üniversitesi bünyesinde öğrenim gören 306 öğrenci üzerinde uygulanmış ve bu öğrenciler üzerinden denemelik ölçeğin çözümlemeleri yapılmıştır. Yapılan analizler sonucu oluşturulan form 296 öğrenci ile tekrar test edilmiş ve yapı geçerliliğine kanıt aranmıştır.

\section{Ölçeğe ait bilgiler}

Dansa yönelik tutum ölçeğine ilişkin maddeler yazılırken öncelikle tutum ve tutum ölçülmesine ilişkin literatür taraması yapılmış, tutuma ilişkin kuramsal yapı (tutumun boyutları: bilişsel, duyuşsal, davranışsal) ve bu kuramsal yapıya uygun hususlar (tutum cümlelerinin ifadesi, içeriğ,. şiddeti vb.) dikkate alınmıştır. Denemelik ölçeğe ilişkin maddeler hazırlanırken bu özellikler göz önüne alınmış ve temsil edilmeye çalışılmıştır. Bunun yanı sıra, başka araştırmacılar tarafından çeşitli konularda hazırlanan tutum ölçekleri de incelenerek (Akandere, Özyalvaç ve Duman, 2010; Güllü, Güçlü ve Arslan, 2009; Kan ve Akbaş, 2005; Karakaş Türker ve Turanl, 2008; Kır, 2012; Koçakoğlu ve Türkmen, 2010; Sanderson, 2000; Şişko ve Demirhan, 2002; Uçal Canakay, 2006; Yoncalık, 2007; Zengin, 2013) madde yazımı aşamasında yararlanılmıştır. Gerekli incelemeler yapıldıktan sonra dansa yönelik tutumu ölçmeye dönük olarak 78 madde oluşturulmuştur. Daha sonra bu ifadeler alan uzmanlarına inceletilerek uzmanların önerileri doğrultusunda 30 madde ölçekten çıkarılmış ve gözden geçirilmiş 48 maddelik nihai deneme formu oluşturulmuştur.

\section{Verilerin analizi}

Oluşturulan 48 maddelik form Gazi Üniversitesi'nde öğrenim gören 340 kişiye uygulanmıştır. Ancak ölçeğin geçerlik ve güvenirlik çalışmaları uygun olmayan ve eksik doldurulmuş formlar çıarıldıktan sonra 306 öğrenci üzerinde yürütülmüştür. Elde edilen veriler üzerinde geçerlik ve güvenirliğe kanıt sağlamak amacıyla aşağıdaki analizler yapılmıştır:

- Güvenirliğe kanit sağlamak amaciyla test tekrar test ve Cr $\alpha$ güvenirlikleri. 
- Madde geçerliğine kanit sağlamak amaciyla madde test korelasyonları.

- Verilerin temel bileşenler analizine uygunluğunu saptamak amacıyla. Kaiser-Meyer Olkin (KMO) katsayısı ve Barlett Sphericity testi.

- Yapı geçerliğine kanıt sağlamak amacıyla doğrulayıcı faktör analizi uygulanmıştır.

- Ölçeğin geçerlik ve güvenirliğine ait bulgular aşağıda verilmiştir.

\section{Bulgular}

\section{Geçerlilik}

Ölçeğin yap1 geçerliğine ilişkin bilgi toplamak amacıyla "döndürülmüş temel bileşenler analizi" kullanılmıştır. Verilerin temel bileşenler analizine uygunluğu Kaiser-Meyer Olkin (KMO) katsayısı ve Barlett Sphericity testi ile incelenmiştir. KMO katsayısı, verilerin ve örneklem büyüklüğünün seçilen analize uygun ve yeterli olduğunu belirlemede kullanılan istatistiksel bir yöntemdir. KMO katsayısı 1'e yaklaştıkça verilerin analize uygun olduğu, 1 olmasında ise mükemmel bir uyum olduğu anlamina gelmektedir (Kan ve Akbaş, 2005). Yapılan analiz sonucunda ilk olarak KMO değeri 0.925 olarak bulunmuştur ancak ölçek maddeleri çıkartıldıktan sonra KMO değerinin 0.932 değerine kadar yükseldiği görülmüştür. Yapılan analiz sonucunda ilk olarak Barlett testi anlamlı bulunmuştur ( $\chi 2=7980.575$; $\mathrm{p}<0.05)$, faktör analizi yapıldıktan ve test maddeleri atıldıktan sonra yapilan Barlett testi analizi sonucu yine anlamlı bulunmuştur ( $\chi 2$ =6757.503; $p<0.05$ ). Öğrencilerin dansa yönelik tutumlarını ölçebilecek anlamlı yapıda ölçme aracına ulaşabilmek, ölçek maddelerinin ölçtügü ve faktör ya da bileşen adı verilen yapı ya da yapıları ortaya çıkarmak amacıyla faktör analizi uygulanmıştır.

Ölçek maddelerine yönelik yapılan faktör analizinde rotated component matrix dikkate alındığında ortaya çıkan 6 faktörlü yapıda, 5. ve 6 . faktörü açıklamak adına her alt boyutta en az 3 madde olması kuralı adına yeterli sayıda olmayan 6. faktördeki 47. madde ile 5. faktördeki 37. madde çıkartılarak analiz işlemine başlanmıştır. Bu maddeler çıkartıldıktan sonra geriye kalan diğer maddeler ile faktör analizi işlemi tekrarlanmış 12. ve 
35. maddeler kesme değerinin altında kalan düşük faktör yükleri sebebiyle formdan çıkartılmıştır. Üçüncü aşamada düşük faktör yüküne sahip olan 43. madde çıkartılarak analiz tekrarlandığında 4 faktörlü bir yapıya ulaşılmıştır. Sonrasında faktörlerde birbirine yük verdiği gözlemlenen 3.,4.,5. ve 22. maddeler çıkartılmıştır. Nihai olarak 3 faktörlü bir yapıya ulaşılmıştır. Sonuç itibariyle uygulanan faktör analizi sonucunda, 48 maddeden oluşan ölçekten, ölçeğin yapısına uymayan ya da birden fazla faktöre yük veren 9 madde $(47,37,12,35,43,3,4,5,22)$ ölçekten çıkarılmıştır. Geriye kalan 39 madde özdeğeri 1'in üzerinde olan 3 alt faktörlü bir yapı oluşturmuştur.

Birinci alt faktör 21 maddeden oluşmaktadır $(1,6,8,10,14$, 18, 20, 24, $27,29,30,31,33,34,36,38,39,41,42,46,48)$ ve yapi içerisinde her bir faktörün önem derecesi ve ağırlığına ilişkin bilgi veren birinci faktöre ait özdeğer 15.52 olarak saptanmıştır. Birinci faktör tek başına varyansın \%33.99'ünü açıklamaktadır. İkinci alt faktör 10 maddeden $(2,7,9$, 13,15, $16,17,19,28,40$ ) oluşmaktadır ve bu faktöre ait özdeğer 6.73 olarak bulunmuştur. Tek başına bu alt faktör ilgili tutum değişkenine ait varyansın \%17.61'ini açıklamaktadır.

Üçüncü alt faktör ise, 9 maddeden $(11,21,23,25,26,32,44,45)$ oluşmaktadır ve bu faktöre ait özdeğer 3.40 olarak bulunmuştur. Tek başına bu faktör ilgili tutum değişkenine ait varyansın \%14.19'unu açıklamaktadır. Bu üç alt faktör birlikte ilgili tutum değişkenine ilişkin varyansın \%65.79'unu açıklamaktadır. Ölçeği oluşturan maddelere ilişkin faktör yükleri 0.51 ile 0.89 arasında değişmektedir. Tüm bu bulgular ölçeğin tatmin edici düzeyde yapı geçerliğine sahip olduğuna ilişkin kanıt olarak görülmektedir. Ölçeğin madde geçerliğine ve homojenliğine ilişkin olarak madde test korelasyonları hesaplanmıştır. Sonuç olarak ölçeğin madde test korelasyonları 0.53 ile 0.84 arasında değer aldığı saptanmıştır. Tüm bu bulgular ölçek maddelerinin geçerliğine ve aynı yapıyı ölçtüğüne kanit olarak ortaya koyulmaktadir. 
Tablo 1. Dansa yönelik tutum ölçeği açımlayıcı faktör analizi

\begin{tabular}{|c|c|c|c|c|c|c|}
\hline Madde & I. & II. & III. & $\begin{array}{c}\text { Cronbach } \\
\text { Alpha } \\
\end{array}$ & $\begin{array}{c}\text { Açıklanan } \\
\text { Varyans } \\
\end{array}$ & Alt Boyut Adı \\
\hline 1 & 0.78 & & & 0.96 & $\% 33.99$ & \\
\hline 6 & 0.77 & & & & & \\
\hline 8 & 0.86 & & & & & \\
\hline 10 & 0.74 & & & & & \\
\hline 14 & 0.76 & & & & & \\
\hline 18 & 0.78 & & & & & \\
\hline 20 & 0.77 & & & & & \\
\hline 24 & 0.85 & & & & & \\
\hline 27 & 0.71 & & & & & Farkındalık \\
\hline 29 & 0.82 & & & & & \\
\hline 30 & 0.72 & & & & & \\
\hline 31 & 0.84 & & & & & \\
\hline 33 & 0.83 & & & & & \\
\hline 34 & 0.68 & & & & & \\
\hline 36 & 0.74 & & & & & \\
\hline 38 & 0.77 & & & & & \\
\hline 39 & 0.73 & & & & & \\
\hline 41 & 0.83 & & & & & \\
\hline 42 & 0.75 & & & & & \\
\hline 46 & 0.77 & & & & & \\
\hline 48 & 0.67 & & & & & \\
\hline 2 & & 0.85 & & & & \\
\hline 7 & & 0.81 & & & & \\
\hline 9 & & 0.86 & & 0.93 & $\% 17.61$ & \\
\hline 13 & & 0.83 & & & & Kaçınma \\
\hline 15 & & 0.91 & & & & \\
\hline 16 & & 0.89 & & & & \\
\hline 17 & & 0.81 & & & & \\
\hline 19 & & 0.86 & & & & \\
\hline 28 & & 0.69 & & & & \\
\hline 40 & & 0.64 & & & & \\
\hline 11 & & & 0.73 & & & \\
\hline 21 & & & 0.74 & 0.90 & $\% 14.19$ & \\
\hline 23 & & & 0.73 & & & \\
\hline 25 & & & 0.84 & & & \\
\hline 26 & & & 0.80 & & & Motivasyon \\
\hline 32 & & & 0.75 & & & \\
\hline 44 & & & 0.70 & & & \\
\hline 45 & & & 0.72 & & & \\
\hline Toplam & & & & 0.91 & $\% 65.79$ & \\
\hline
\end{tabular}




\section{Güvenirlik}

Ölçeğin güvenirliğine ilişkin olarak. tüm ölçek için ve her bir alt boyut için ayrı ayrı Cra güvenirlik katsayıları hesaplanmıştır. Ölçeğin tümüne ait $\mathrm{Cr} \alpha$ güvenirliği; 0.91, birinci alt faktöre ilişkin $\mathrm{Cr} \alpha$; 0.96, ikinci alt faktöre ilişkin $\mathrm{Cr} \alpha ; 0.93$, üçüncü alt faktöre ilişkin $\mathrm{Cr} \alpha ; 0.90$ olarak bulunmuştur.

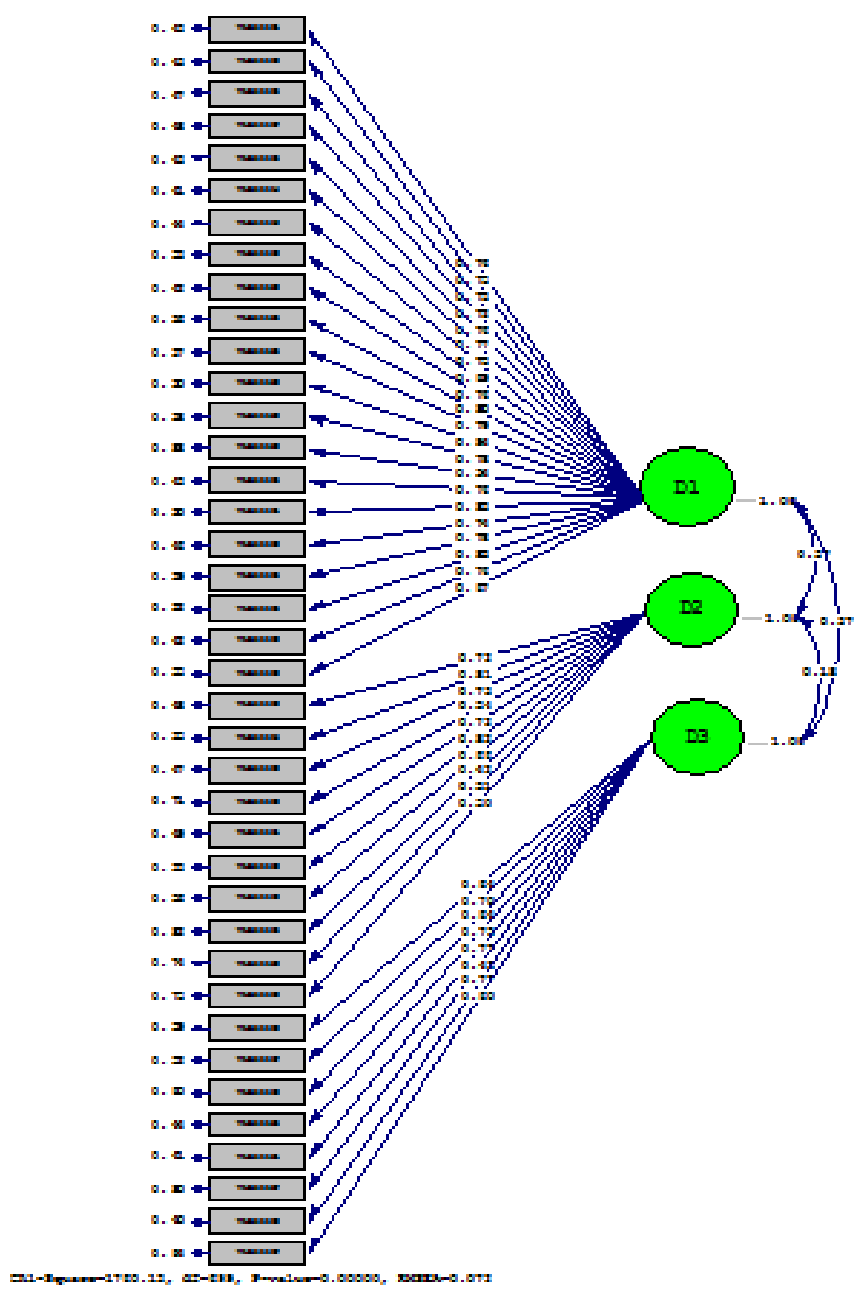

Şekil 1. Doğrulayıcı faktör analizi diyagramı 
Tüm bu bulgular ölçeğin tatmin edici düzeyde güvenirliğe sahip olduğuna ilişkin kanıt olarak görülmektedir. Dansa yönelik tutum ölçeğinden elde edilen puanlarla alt faktörlere ait puanlar arasındaki korelasyonlar 0.53 ile 0.84 arasında değişmektedir ve bu korelasyon katsayıları 0.01 düzeyinde anlamlı bulunmuştur. Korelasyonların yüksek ve anlamlı olması bu üç alt faktörün dansa yönelik tutumun bileşeni olduğunu göstermektedir. Ayrıca alt faktörler arasında yapılan korelasyon analizi sonucunda; 1 . alt faktör ile 2 . alt faktör arasında ters yönde anlamlı bir ilişki gözlenirken, 1 . alt faktör ile 3. alt faktör arasında pozitif yönde anlamlı bir ilişki saptanmıştır. 2. alt faktör ile 3. alt faktör arasında negatif yönde anlamlı bir ilişki gözlemlenmiştir.

İkinci uygulama sonrası yapılan doğrulayıcı faktör analizi sonuçlarının uyum ölçüleri içerisinde olduğu ve yapı geçerliliğine kanıt oluşturduğu görülmektedir (RMSA 0.072, SRMR 0.06, x²/df 2.518).

Tablo 3. Uyum ölçüleri ve model uyumu için sınır değerleri

\begin{tabular}{lllll}
\hline Uyum Ölçüsü & $\begin{array}{l}\text { İdeal } \\
\text { Uygunluk } \\
\text { Değerleri }\end{array}$ & $\begin{array}{l}\text { Kabul } \\
\text { Edilir Uyum }\end{array}$ & Uyumsuzluk & $\begin{array}{l}\text { Elde } \\
\text { edilen } \\
\text { değerler }\end{array}$ \\
\hline RMSA & $0-0.05$ & $0.05-0.09$ & $>0.10$ & 0.072 \\
SRMR & 1 & $0.90-0.99$ & $<0.90$ & 0.067 \\
$\mathbf{x}^{2} / \mathbf{d f}$ & $<=2$ & $2-5$ & $5+$ & 2.518 \\
\hline
\end{tabular}

(Özdamar, 2016; Özdamar, 2013)

\section{Tartışma ve sonuç}

Araştırmada bireylerin dansa yönelik tutumlarını ölçmeye yönelik ölçme aracı geliştirmek amaçlanmıştır. Nitel veriler ve literatür ışığında oluşturulan 78 maddeden oluşan soru havuzu, maddeler uzman görüşleri alınarak 48 maddeye düşürülmüş, pilot çalışma sonrası oluşan ölçeğin denemelik formu Gazi Üniversitesi'nde eğitim-öğretim gören 306 öğrenci üzerinde uygulanmıştır. Elde edilen veriler üzerin yapılan $\mathrm{KMO}(0.93)$ ve Barlett (6757.503; p<0.001) testi sonucu örneklem sayısının faktör analizi yapılmasının uygun olduğu belirlenerek, ölçeğin geçerliğine ilişkin bilgi elde edebilmek için döndürülmüş temel bileşenler analizi kullanılmıştır. Kesme değerinin 0.40 olarak alındığı açımlayıcı faktör analizi sonrası 0.53 
ila 0.84 arasında değişen faktör yükleri ile ölçeğin üç alt faktörlü bir yapıya sahip olduğu belirlenmiş, toplam varyansın \%65'inin açıklandığı ölçek maddeleri 39 maddeye düşürülmüştür. İç tutarlılık katsayıları sırasıyla 0.96, 0.93, 0.90 olarak saptanan alt boyutlar dansa yönelik farkındalık, kaçınma, motivasyon alt boyutları olarak adlandırılmıştır. Madde geçerliğine kanıt olarak madde test korelasyonları hesaplanmıştır. Madde test korelasyonlarının 0.53 ile 0.84 arasında değiştiği saptanmıştır. Ayrıca ölçeğin tamamının güvenirliğine kanıt sağlamak amacıyla $\mathrm{Cr} \alpha$ güvenirlikleri hesaplanmış ve 0.91 olarak bulunmuştur. Yapılan test tekrar test ile 296 katılımcıya ulaşılarak yapı geçerliliğine kanıt aranmıştır. Yapılan doğrulayıcı faktör analizi sonuçları (RMSA 0.072, SRMR 0.067, x²/df 2.518) yapıya kanıt oluşturacak nitelikte olduğu saptanmıştır. Sonuç olarak çalışmada analiz edilen ölçüm aracının dansa yönelik tutumu ölçmede geçerli ve güvenilir bir ölçüm aracı olduğu belirlenmiştir.

Araştırmada dansa yönelik tutum ölçeğinin geliştirilmesine yönelik yapılan araştırmalar dansa yönelik tutumu ölçmede geçerli ve güvenilir bir ölçüm aracı ortaya koymayı destekler niteliktedir. Literatürde dansa yönelik tutum ölçeklerine sıkça rastlanmamakla birlikte ülkemizde bu konudaki çalışmalar oldukça sınırlıdır. İngiltere'de Sanderson'ın (2000) 1116 yaş aralığındaki katılımcılar üzerinde yaptığı araştırma bulgularımıza benzer olarak \%73.1 gibi yüksek bir değerde varyansın açıklandığı, kesme değerinin araştırmada 0.40 olarak belirlediğimiz kesme değerinin çok altında 0.20 olarak belirlenen kesme değerinde olduğu, iç tutarlılık katsayılarının 0.64 ila 0.87 arasında değiştiği 32 maddeden oluşan ölçüm aracının araştırmamızla benzer şekilde geçerli güvenilir bir ölçüm aracı olarak ortaya koyulduğu görülmektedir. Bir diğer araştırmada, Yoncalık (2007) 241 üniversite öğrencisinin katılımıyla yaptığ çalışmada beden eğitimi ve spor alanında öğrenim gören üniversite öğrencilerinin dans kavramına yönelik tutumlarının cinsiyetleri üzerinden değerlendirmiştir. Araştırma sonuçlarına göre katılımcılar cinsiyet ayrımı olmaksızın dansı bir spor branşı olarak kabul eden bir tutum sergiledikleri görülmüştür. bunun yanı sıra kız öğrencilerin dansa yönelik tutumlarının erkek öğrencilerden daha olumlu olduğu belirlenmiştir.

Literatürde dansa yönelik tutum çalışmalarından ziyade öğrencilerin beden eğitimi dersine yönelik tutum düzeylerinin araştırılması söz konusudur. Bunlardan biri olan; Kır'ın (2012) ilköğretim ikinci kademe 
öğrencilerinin beden eğitimi dersine ilişkin tutumlarını belirlenmesine yönelik yapılan araştırmada, öğrencilerin kişisel özelliklerine göre beden eğitimi dersine ilişkin tutumları arasındaki farklılıkları tespit etmek suretiyle, derse ilginin, ders saatinin ve ders öğretmeni özelliklerinin öğrencinin derse yönelik tutumları üzerindeki etkilerinin incelenmesi hedeflenmiş, yapılan analizler sonucunda beden eğitimi dersine ilişkin tutumlarının olumlu olduğu bulunmuştur. Güllü, Güçlü ve Arslan (2009). Şişko ve Demirhan (2002) ve Zengin'in (2013) yaptıkları araştırmalarda benzer bulgular elde edilerek çalışma gruplarının beden eğitimi dersine ilişkin tutumlarının olumlu olduğu belirlenmiştir. Bir diğer araştırmada ortaöğretim öğrencilerinin beden eğitimi dersine yönelik tutumları ile akademik başarı motivasyonlarının incelenmesi amaçlanmıştır. Araştırma bulguları beden eğitimi dersine yönelik tutum ile akademik başarı motivasyonu arasındaki ilişkinin başarıyı etkilediğini göstermektedir (Akandere, Özyalvaç ve Duman, 2010).

Sonuç olarak dansa yönelik tutum ölçeğinin yapılan analiz kapsamında geçerli ve güvenilir bir yapıya sahip olduğu saptanmıştır. Analiz sonuçları bu durumu destekler niteliktedir. Dans olgusunun gelişimi, ülkemizde daha fazla yer edinmesi büyük önem taşımaktadır. Bireylerin dansa yönelik tutumları ölçülerek, yapılan taramalar doğrultusunda gerekli araştırmalar ve çalışmalara ışık tutacak veriler elde etmek amaçlanmıştır. Bu bağlamda antrenman programları, dansa yönelik rekreatif faaliyetler düzenlenebilir ve faaliyet programlarına eklemeler yapılabilir. Ülkemizde kültürel bir meta olarak görülen dansın özellikle çalışmaya katılan bireylerin gözünde benimsenmiş bir aktivite olduğu göze çarpmaktadır. Spor politikaları dahilinde dans aktivitelerine katılımı destekleyen çalışmalar yapılması ve programlar oluşturulması önerilmektedir. Ülkemizde dans alanında yapılmış akademik çalışmaların azlığı göze çarpmaktadır. Literatüre katkı sağlaması açısından farklı gruplarla dansa olan ilginin ve psikolojik alt faktörlerin araştırıldı̆̆ çalışmalar yapılarak bu bağlamda literatürün genişletilmesi öneriler arasindadir. 


\title{
EXTENDED ABSTRACT
}

\section{Development of Attitude ScaleTowards Dance}

\author{
Tebessüm Ayyıldız Durhan
}

Gazi University

The dance is defined as, the expression and manifestation of human's mental state by some bodily movements Dans (Emiroğlu and Aydın, 2003). Sensing the rhythms of the mind in the nature or hearing the sound of the music. stimulation of consciousness as a result of the body, according to the temporal and spatial forms act (Tercan, 2016). The dance which has different dimensions is the physical and emotional behavior which is the result of a creativity with aesthetic and rhythmic characteristic brought by the community of movements, which means meaning to be able to express their own feelings and thoughts and communicate with the society (Aktaş, 1999). It is seen that emotions, thoughts and behaviors of individuals should be examined in order to learn the attitudes of individuals. It is possible to observe the behavior of individuals. However, this may not always explain the individual's attitude exactly. In addition, an existing attitude remained in the dimension of thought, but could not have turned into behavior. For this reason, different attitude scales have been developed to measure the attitudes of individuals (Koçakoğlu and Türkmen, 2010). Identifying attitudes towards an object, object or individual can be achieved in several ways. These are shifts from physiological responses, comprehensate from open behaviors and scale development (Kan and Akbaş, 2005).

In the study, after the question pool was transformed into a test form. the form was tested by applying to the form 50 students to test the comprehensibility of the measurement tool. The first application was made by determining the form to be understandable in general terms. The 48-item form was applied to 340 people studying at Gazi University. However, the validity and reliability studies of the scale were carried out on 306 students after removing the inappropriate and incomplete forms. KMO (0.93) and 
Barlett (6757.503; $\mathrm{p}<0.001)$ tests were performed on the obtained data and the principal components analysis was used to determine the number of samples for the purpose of factor analysis and to obtain information about the validity of the scale. With the factor loadings ranging from 0.53 to .84 after the cut-off value was taken as 0.40 , it was determined that the scale had a structure with three sub-dimension and the scale items which explained $65 \%$ of the total variance were reduced to 39 items. The internal consistency coefficients were determined as $0.96,0.93,0.90$. respectively. With the test re-testing, 296 participants were searched for evidence of construct validity. Factor analysis was applied in order to reach the measurement tool which can measure the attitudes of the students towards dancing, to measure the scale items and to reveal the structures or structures called factors or components. Confirmatory factor analysis results (RMSA 0.072, SRMR 0.067, $\mathrm{x}^{2}$ / df 2.518) were found to be evidence for the structure. All these findings are seen as evidence that the scale has satisfactory reliability. The correlations between the scores obtained from the attitude scale and the scores of the sub-dimensions ranged from 0.53 to 0.84 , and these correlation coefficients were found to be significant at a level of 0.01 . The fact that the correlations are high and meaningful indicates that these three sub-dimensions are the components of attitude towards dancing. In addition, as a result of the correlation analysis between the sub-factors; while a negative correlation was found between the 1st and 2 nd sub-dimensions. there was a positive correlation between the 1st sub-dimension and the third sub-dimension. A negative significant correlation was observed between the 2 nd sub-dimension and the third subdimension.

As a result, it was found that the attitude towards dance was valid and reliable. Analysis results support this situation. The development of the phenomenon of dance is of great importance in our country. By measuring the attitudes of individuals towards dance, it is aimed to obtain data that will shed light on the necessary researches and studies in line with the scans. In this context, training programs, recreational activities can be organized and additions to activity programs can be made. It is observed that the dance which is seen as a cultural commodity in our country is an adopted activity especially in the eyes of the participants. Within the scope of sports policies, it is recommended to carry out studies and programs to 
support participation in dance activities. The scarcity of academic studies in the field of dance is remarkable in our country. In order to contribute to the literature, it is suggested that studies on different sub-groups of interest and psychological sub-factors are investigated and the literature is expanded in this context.

\section{Kaynakça / References}

Aktaş, G. (2012). Dans'a ilk adım, içinde (s. 21-22). İzmir: Ege Üniversitesi Basımevi.

Akandere, M., Özyalvaç, N. T. ve Duman. S. (2010). Ortaöğretim öğrencilerinin beden eğitim dersine yönelik tutumları ile akademik başarı motivasyonlarının incelenmesi:Konya Anadolu Lisesi örneği. Selçuk Üniversitesi Sosyal Bilimler Enstitüsü Dergisi. 24, 1-10.

Emiroğlu, K. ve Aydın, S. (2003). Etnoloji sözlüğ̈̈̈, içinde (s.204-205). Ankara: Bilim ve Sanat Yayınevi.

Galioğlu, A. (2007). İzmir'deki latin kursları ve dans pratiğinin içerdiği cinsellik.Yüksek Lisans Tezi. Dokuz Eylül Üniversitesi Güzel Sanatlar Enstitüsü. İzmir.

Güllü, M.. Güçlü, M. ve Arslan, M. (2009). Ortaöğretim öğrencilerinin beden eğitimi dersine ilişkin tutumlarının incelenmesi. e-Journal of New World Sciences Academy Sports Sciences. 4(4), 273-288.

Kan, A. ve Akbaş, A. (2005). Lise öğrencilerinin kimya dersine yönelik tutum ölçeği geliştirme çalışması. Mersin Üniversitesi Eğitim Fakültesi Dergisi. 1(2), 227-237.

Karakaş, T. N. ve Turanll, N. (2008). Matematik eğitimi derslerine yönelik tutum ölçeği geliştirilmesi. GÜ. Gazi Ĕ̆itim Fakültesi Dergisi. 28(3), 17-29.

Kır, R. (2012). Illköğretim II. kademe öğrencilerinin beden eğitimi ve spor dersine yönelik tutum ve davranışları:Kırıkkale örneği. Yüksek Lisans Tezi, Kırıkkale Üniversitesi Sağlık Bilimleri Enstitüsü.Kırıkkale.

Koçakoğlu, M. ve Türkmen, L. (2010). Biyoloji dersine yönelik tutum ölçeği geliştirilmesi. Ahi Evran Üniversitesi Eğitim Fakültesi Dergisi. 11(2), 229-245.

Sanderson, P. (2000). The development of dance attitude scales. Educational Research. 42(1), 91-99. 
Şişko, M. ve Demirhan, G. (2002). İlköğretim okulları ve liselerde öğrenim gören kız ve erkek öğrencilerin beden eğitimi ve spor dersine ilişkin tutumları. Hacettepe Üniversitesi Eğitim Fakültesi Dergisi. 23, 205-210.

Tercan, C. (2016). Topluma katılım aracı olarak dans. Yüksek Lisans Tezi, Balıkesir Üniversitesi Sosyal Bilimler Enstitüsü Sosyoloji Anabilim Dalı. Balıkesir.

Türk Dil Kurumu. (2005). Türkçe sözlük (10. bask1). Ankara: TDK.

Uçal Canakay, E. (2006). Müzik teorisi dersine ilişkin tutum ölçeği geliştirme. Ulusal Müzik Eğitimi Sempozyumu Bildirisi. Denizli. 2628 Nisan 2006. 297-310.

Yoncalık, O. (2007). Kültür ve spor bağlamında cinsiyetin "dans"a yönelik tutuma etkisi:Beden eğitimi ve spor alanında öğrenim gören öğrenciler üzerinde yapılan bir analiz. Milli Eğitim Dergisi. 176, 109-118.

Zengin, S. (2013). Çocuk ve gençlik merkezlerinde hizmet alan 12-18 yaş arası erkek çocuklarının beden eğitimi ve spor dersine yönelik tutum düzeyleri ile benlik saygılarının incelenmesi. Yüksek Lisans Tezi, Sakarya Üniversitesi Eğitim Bilimleri Enstitüsü. Sakarya.

\section{Kaynakça Bilgisi / Citation Information}

Ayyıldız Durhan, T. (2019). Dansa yönelik tutum ölçeği geliştirme çalışması. OPUS-Uluslararası Toplum Araştırmaları Dergisi. 11(18), 676692. DOI: $10.26466 /$ opus. 552080

Ek 1. Dansa yönelik tutum ölçeği madde göstergeleri

\begin{tabular}{c|l}
\hline Alt boyut adı & \multicolumn{1}{|c}{ Maddeler } \\
\hline Farkındalık & $1-3-5-7-10-14-16-19-22-24-25-26-28-29-30-31-32-34-35-38-39$ \\
Kaçınma & $2^{*}-4^{*}-6^{*}-9^{*}-11^{*}-12^{*}-13^{*}-15^{*}-23^{*}-33^{*}$ \\
Motivasyon & $8-17-18-20-21-27-36-37$ \\
\hline
\end{tabular}

*Ters kodlanan maddeler 


\section{Ek2. Dansa yönelik tutum ölçeği}

\begin{tabular}{|c|c|c|c|c|c|}
\hline & 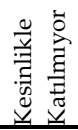 & 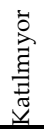 & 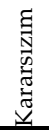 & 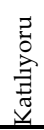 & 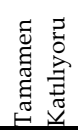 \\
\hline \multicolumn{6}{|l|}{ 1. Dans bireylerin mutlu olmasını sağlayan bir aktivitedir. } \\
\hline \multicolumn{6}{|l|}{ 2. Dans aktivitelerinde sıkılırım. } \\
\hline \multicolumn{6}{|l|}{ 3. Dans bireylerin çevre ile olan uyumunu arttırır. } \\
\hline \multicolumn{6}{|l|}{ 4. Dans aktivitelerinin olduğu ortamlardan kaçınırım. } \\
\hline \multicolumn{6}{|l|}{$\begin{array}{l}\text { 5.Dans bireylerin kabiliyetlerinin farkına } \\
\text { varmasını sağlayan bir aktivitedir. }\end{array}$} \\
\hline \multicolumn{6}{|l|}{ 6. Dansın zaman kaybı olduğuna inanırım. } \\
\hline \multicolumn{6}{|l|}{ 7. Dans sosyalleşmemi olumlu yönde etkiler. } \\
\hline \multicolumn{6}{|l|}{ 8. Dans aktivitelerini sabırsızlıkla beklerim. } \\
\hline \multicolumn{6}{|l|}{ 9. Dans bireylerde stres yaratan bir aktivitedir. } \\
\hline \multicolumn{6}{|l|}{ 10. Dansın bireylerin yaşam kalitesini arttırdığına inanırım. } \\
\hline \multicolumn{6}{|l|}{ 11.Dans dendiğinde kaygı duyarım. } \\
\hline \multicolumn{6}{|l|}{ 12.Danstan hoşlanmam. } \\
\hline \multicolumn{6}{|l|}{ 13.Dansın sakatlığa yol açtığını düşünürüm. } \\
\hline \multicolumn{6}{|l|}{ 14.Dans bireyleri zihinsel açıdan dinlendirir. } \\
\hline \multicolumn{6}{|l|}{ 15.Dansı başkalarına önermem. } \\
\hline \multicolumn{6}{|l|}{ 16.Dans estetik duygularımı geliştirir. } \\
\hline \multicolumn{6}{|l|}{ 17.Boş zamanlarımda dans aktivitelerine katılırım. } \\
\hline \multicolumn{6}{|l|}{ 18. Dans ile ilgili tartışmalara katılırım. } \\
\hline \multicolumn{6}{|l|}{ 19.Dans özgüveni arttıran bir aktivitedir. } \\
\hline \multicolumn{6}{|l|}{ 20. Dansa büyük ölçüde zaman ayırırım. } \\
\hline \multicolumn{6}{|l|}{ 21. Dansta başarılı olmak için çaba sarf ederim. } \\
\hline \multicolumn{6}{|l|}{ 22. Dans bireylerin girişimcilik duygusunu arttıran bir aktivitedir. } \\
\hline \multicolumn{6}{|l|}{ 23.Dansta kendimi rahat hissetmem. } \\
\hline \multicolumn{6}{|l|}{ 24.Dans bireylerin yaratıcılığını geliş̧iren bir aktivitedir. } \\
\hline \multicolumn{6}{|l|}{ 25. Dansın ayrıcalıklı bir aktivite olduğunu düşünürüm. } \\
\hline \multicolumn{6}{|l|}{$\begin{array}{l}\text { 26.Dansın bireylerin kendini ifade etmesinde bir } \\
\text { araç olduğuna inanırım. }\end{array}$} \\
\hline 27.Dansta başarılı olmak benim için önemlidir. & & & & & \\
\hline 28. Dans bireylerin vücutlarıyla ilgili farkındalık yaratır. & & & & & \\
\hline 29.Dans bireylerin yaşam tarzını yansıtır. & & & & & \\
\hline 30.Dansta fiziksel olarak kendimi zinde hissederim. & & & & & \\
\hline 31.Dansta bireylerin iş birliği duyguları gelişir. & & & & & \\
\hline 32. Dansi severim. & & & & & \\
\hline 33.Dansın gelecek yaşamıma katkı sağlayacağını düşünmem. & & & & & \\
\hline 34.Dansın bireyin sağlıklı gelişimine katkı sağladığını düşünü & & & & & \\
\hline $\begin{array}{l}\text { 35. Dans bireylerin hareket koordinasyonunu } \\
\text { olumlu yönde etkiler. }\end{array}$ & & & & & \\
\hline 36.Diğer aktiviteler yerine dansı tercih ederim. & & & & & \\
\hline 37.Dans ile ilgili basılı yayınları takip ederim. & & & & & \\
\hline 38.Dans duygu bütünlüğü ile ortaya çıkan bir aktivitedir. & & & & & \\
\hline 39. Dans bireylere liderlik özelliği kazandıran bir aktivitedir. & & & & & \\
\hline
\end{tabular}

